\title{
TOŻSAMOŚĆ WOJOWNIKA W GRUPIE KRAKOWSKO-SANDOMIERSKIEJ KULTURY CERAMIKI SZNUROWEJ
}

\author{
WARRIOR IDENTITY IN THE CRACOW-SANDOMIERZ \\ GROUP OF CORDED WARE CULTURE
}

\author{
Rafat Skrzyniecki \\ Instytut Prahistorii, Uniwersytet im. Adama Mickiewicza \\ ul. Św. Marcin 78, 61-809 Poznań, Poland
}

\begin{abstract}
The main issue of this paper is to identify men-warriors within the Cracow-Sandomierz Group of Corded Ware culture burials and attempt to reconstruct combat techniques undertaken by them. To achieve this goal, a comprehensive analysis of selected burials has been conducted. These selected burials had to meet strict criteria such as: particular body arrangement, sex, age, and presence of certain grave goods, particularly weapons. The examination of differences within grave goods and relations between their categories, as well as sex, age, and body arrangement of the deceased clearly shows that the Cracow-Sandomierz group of Corded Ware culture encompassed a specific pattern of identity strongly related to manhood, possession of arms and, most likely, armed combat.
\end{abstract}

\section{WPROWADZENIE}

U progu III tysiąclecia BC na obszarze położonym na północ od Alp krystalizuje się zwyczaj wyposażania wybranych pochówków, w szczególności męskich, w broń. Jest on szczególnie czytelny wśród społeczności kultur z ceramiką sznurową ${ }^{1}$. Na początkowym etapie rozwoju omawianych ugrupowań zmarłych wyposażano przede wszystkim w kamienne topory oraz długie, smukłe ostrza krzemienne, stanowiące prawdopodobnie głownie sztyletów lub noży. Z czasem asortyment ten poszerzył się o relikty sprzętu łuczniczego w postaci krzemiennych grotów strzał oraz siekiery wykonane $\mathrm{z}$ tego samego surowca. Według niektórych badaczy kultury ceramiki sznurowej upowszechnienie się zwyczaju wyposażania zmarłych w broń można odczytywać jako przejaw kształtowania się nowej kolektywnej tożsamości

\footnotetext{
${ }^{1}$ Kruk, Milisauskas 1999; Czebreszuk 2001; Vandkilde 2006b; Włodarczak 2006.
} 
społecznej, ściśle związanej z męskością, reprezentowanej przez grupy mężczyznwojowników ${ }^{2}$. Przypuszcza się, że materialnym dowodem na funkcjonowanie tejże grupy w omawianych społecznościach są pochówki męskie o określonym układzie ciała $\mathrm{w}$ jamie grobowej oraz zestandaryzowanym wyposażeniu militarnym.

Celem niniejszego artykułu jest identyfikacja mężczyzn-wojowników w grupie krakowsko-sandomierskiej kultury ceramiki sznurowej (dalej: g. K-S KCSz). Przyjęta metoda realizacji tego celu polega na przeprowadzeniu wielopłaszczyznowej analizy pochówków spełniających odpowiednie kryteria, pozwalające na przypisanie zmarłym funkcji wojowników. Ze względu na konieczność uchwycenia relacji między poszczególnymi kategoriami wyposażenia grobowego a płcią, wiekiem oraz układem zwłok zmarłego badaniu poddano przede wszystkim dobrze zachowane pochówki, posiadające dodatkowo antropologiczne oznaczenia płci i wieku. Obok obecności broni w grobie były to zatem dwa podstawowe kryteria doboru źródeł.

W niniejszym tekście dość często pojawiać się będzie pojęcie tożsamości, szczególnie w odniesieniu do wojowników społeczności g. K-S KCSz. W związku z tym uznano za konieczne przytoczenie definicji omawianego terminu oraz krótką charakterystykę jego wariantu związanego z działalnością wojownika.

Obszerna analiza wybranych pochówków wojowników z g. K-S KCSz stanowiła główną część pracy magisterskiej pt. „Tożsamość wojownika w grupie krakowsko-sandomierskiej kultury ceramiki sznurowej"3, obronionej przez autora niniejszego tekstu w Instytucie Prahistorii Uniwersytetu im. Adama Mickiewicza. Ten artykuł stanowi w dużej mierze syntezę treści tejże pracy. W związku z tym podjęto decyzję o zaprezentowaniu kluczowych aspektów dotyczących specyfiki bazy źródłowej, przyjętych metod analitycznych oraz interpretacji uzyskanych wyników.

\section{TOŻSAMOŚĆ WOJOWNIKA}

Zwartą i sugestywną definicję pojęcia tożsamości dał R. Jenkins ${ }^{4}$. Określa ona tożsamość jako systematyczny proces przedstawiania oraz tworzenia charakterystycznego zespołu podobieństw i różnic między poszczególnymi jednostkami, grupami, bądź jednostkami i grupami. Jednocześnie podkreśla, że nie jest ona owocem jednorazowego aktu twórczego, gdyż kształtuje się w czasie. Stanowi przy tym wypadkową wielu kategorii społecznych, m.in. płci kulturowej, wieku, statusu społecznego, profesji czy etniczności.

Niezbędne podłoże dla formowania się tożsamości wojownika stanowi środowisko społeczno-kulturowe, obfitujące w akty przemocy i konflikty. W swojej rozwi-

\footnotetext{
${ }^{2}$ Kruk 2008; Vandkilde 2006b.

${ }^{3}$ Skrzyniecki 2012.

${ }^{4}$ Jenkins 1996, 21, 22.
} 
niętej postaci funkcjonuje ona również w czasie pokoju. Jednym z fundamentów jej trwania staje się wówczas bezkrwawy proces interakcji między członkami danej społeczności ${ }^{5}$.

Tożsamość wojownika ma, jak wskazano powyżej, wymiar kolektywny. Działań wojennych nie da się bowiem prowadzić w pojedynkę. Niemniej jednak jej motorem napędowym jest również indywidualizm, gdyż pragnieniem każdego wojownika jest zdobycie osobistej sławy ${ }^{6}$. Bycie wojownikiem ma ponadto dwoisty wymiar społeczno-ideologiczny: jest on osobnikiem reprezentującym często opozycyjne względem siebie wartości (np. okrucieństwo i męstwo). Dwoistość jego natury wynika z nieustannego przekraczania symbolicznej granicy między tym, co znane i zrozumiałe, a tym, co obce i niepojęte. Pośród wrogów sieje on zamęt i zniszczenie, zdobywając tym samym szacunek i uznanie wśród swoich ${ }^{7}$.

Warriorhood (czyli tożsamość wojownika) stanowi zatem wypadkową wielu tożsamości funkcjonujących $\mathrm{w}$ danej populacji, a w szczególności tych związanych z kategoriami wieku i płci, a niekiedy również pozycji społecznej. Może się także łączyć z wykonywaną profesją. Ponadto nie jest to konstrukt stały, niezmienny. Podlega bowiem dyferencjacji zachodzącej w czasie. Przykładem ilustrującym niniejszy pogląd jest zjawisko formowania się naturalnego podziału na mniej i bardziej sprawnych wojowników. Różnice w skuteczności bojowej tworzą z kolei bazę dla kolejnego podziału, którego podstawowym kryterium jest sława - im lepiej wojownik radzi sobie w boju, tym większa chwała staje się jego udziałem.

\section{POCHÓWKI WOJOWNIKÓW W GRUPIE KRAKOWSKO-SANDOMIERSKIEJ KULTURY CERAMIKI SZNUROWEJ}

Baza źródłowa omawianego zagadnienia obejmuje 53 groby grupy krakowsko-sandomierskiej kultury ceramiki sznurowej, w których przy zmarłych odnaleziono przedmioty o charakterze militarnym ${ }^{8}$ (ryc. 1). Za najważniejsze kryterium doboru źródeł przyjęto obecność militariów w grobie. Preferowano przy tym pochówki zawierające oznaczenia antropologiczne płci i wieku, w związku z czym z dostępnej puli obiektów wybrano te zawierające bardzo dobrze zachowane szczątki ludzkie. Znaczna liczba grobów przedstawicieli g. K-S KCSz spełniała powyższe warunki.

Trzynaście obiektów pochodzi z nekropoli w Żernikach Górnych, 11 z cmentarzyska w Mierzanowicach stan. $1^{9}$, pozostałe natomiast zarejestrowano jako obiekty

\footnotetext{
${ }^{5}$ Jenkins 1996, 21, 22.

${ }^{6}$ Vandkilde 2006, 396.

${ }^{7}$ Vandkilde 2006, 396.

${ }^{8}$ Skrzyniecki 2012.

${ }^{9}$ Salewicz 1937; Uzarowiczowa 1970.
} 


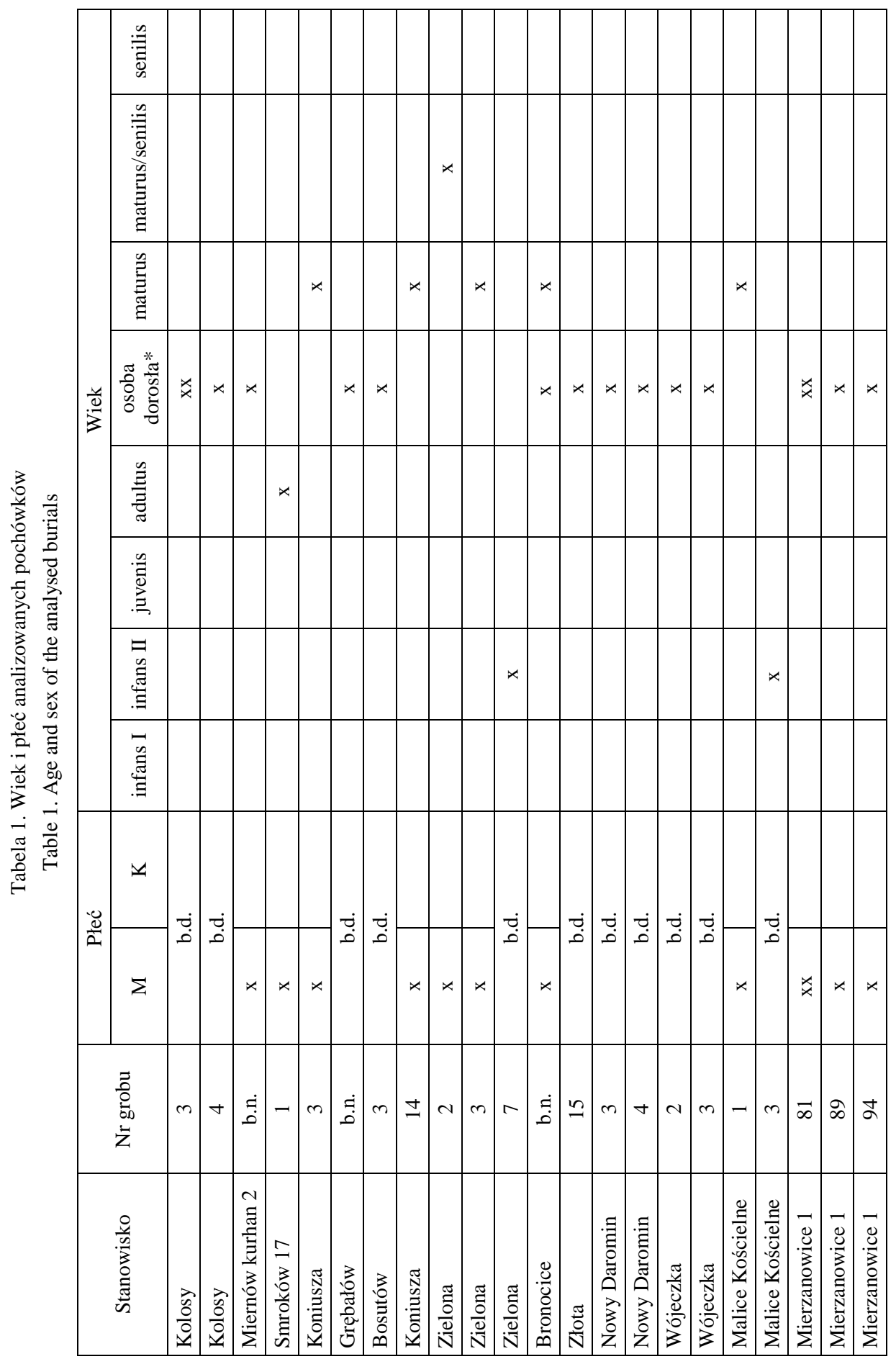




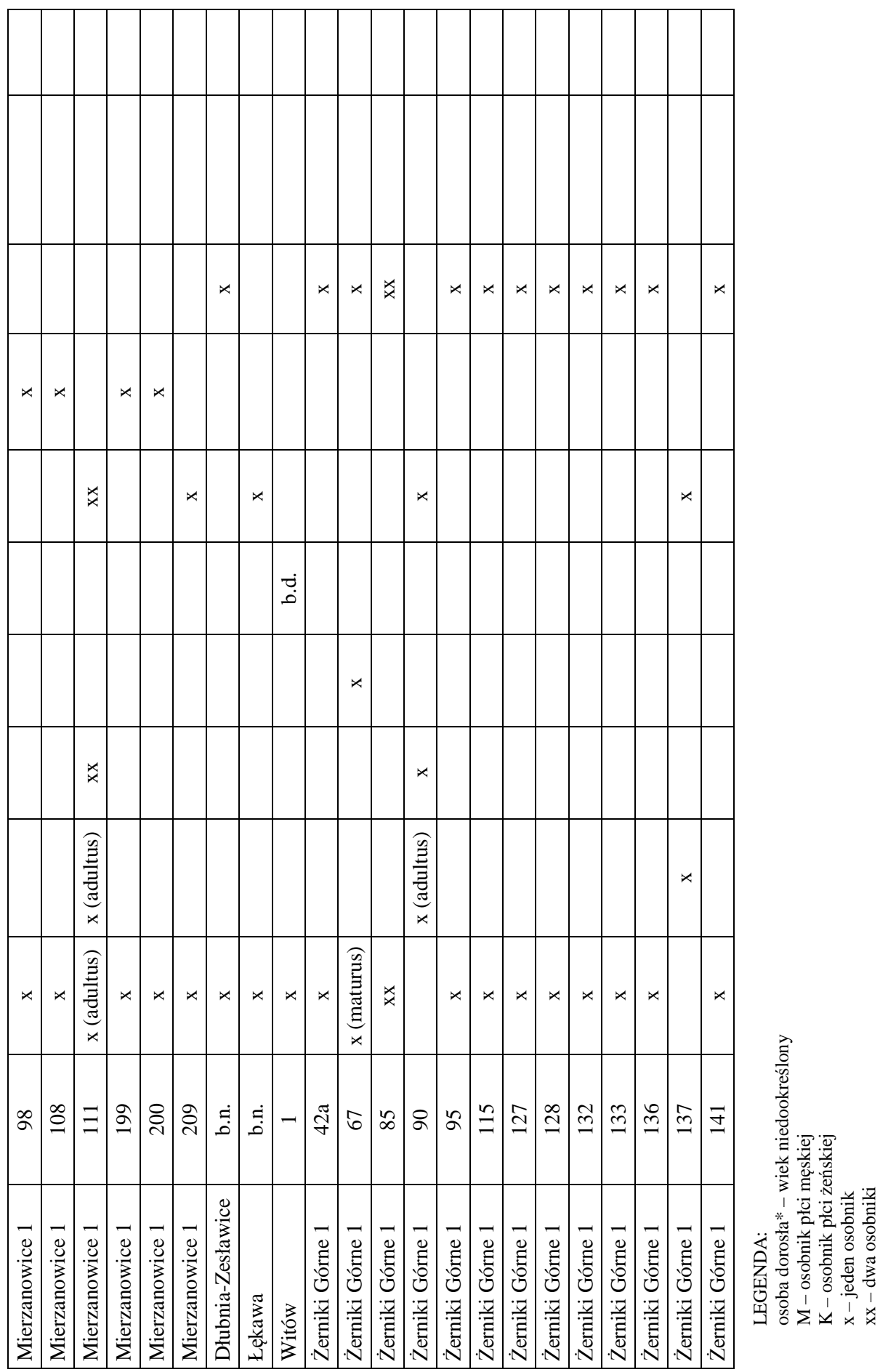




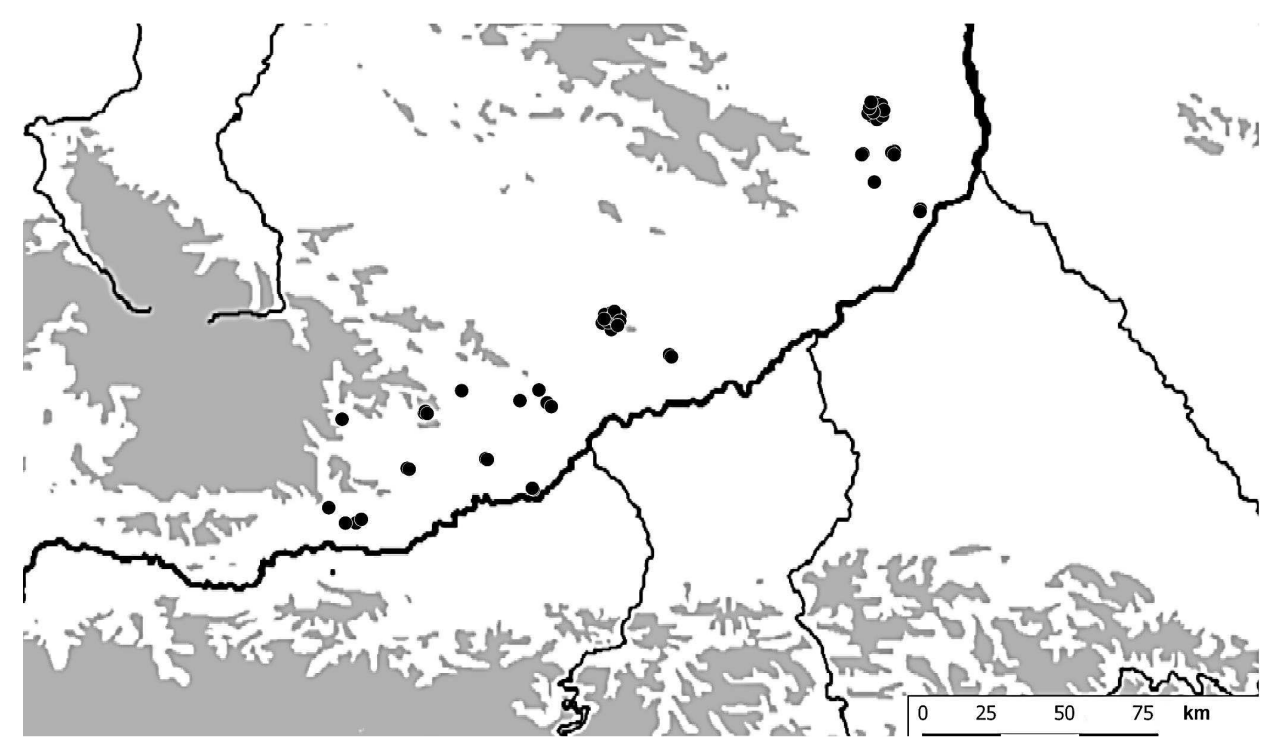

Ryc. 1. Mapa rozmieszczenia pochówków wojowników w grupie krakowsko-sandomierskiej KCSz

Fig. 1. Map of the CWC-KSG warrior burials

pojedyncze lub w granicach niewielkich cmentarzysk. Typ konstrukcji określono dla 50 grobów. W analizowanej grupie dominowały konstrukcje niszowe i jamowe (odpowiednio 24 i 23 groby), w trzech przypadkach nad grobem usypano kurhan. Dwa groby zaklasyfikowano jako tzw. kenotafy, gdyż nie odnaleziono w nich szczątków kostnych. W omawianym materiale nie odnalzeiono w nich między kategoriami płci/wieku a typem konstrukcji grobu. Dla 36 pochowków udało się ustalić płeć: 33 zaklasyfikowano jako męskie, trzy natomiast należały do kobiet. W przypadku pozostałych 17 grobów wiarygodna weryfikacja płci okazała się niemożliwa. Wiek ustalono w 31 przypadkach. Wśród pochowanych z bronią zdecydowanie dominowały osoby dorosłe w wieku maturus (19 osobników) i adultus (6). Wiek sześciu osób określono ogólnie jako infans ${ }^{10}$ (tab. 1).

\section{Uzbrojenie oraz pozostałe kategorie darów grobowych}

Wyposażenie militarne w omawianej grupie pochówków obejmowało: topory kamienne, łuki, strzały, po których pozostały ich groty, zróżnicowane formy krzemiennych ostrzy wiórowych i siekiery krzemienne. Przy zmarłych odnajdywano również depozyty półsurowca krzemiennego, przedmioty kościane i rogowe, szable

\footnotetext{
${ }^{10}$ Skrzyniecki 2012.
} 
dzika oraz, aczkolwiek zdecydowanie rzadziej, ozdoby. Wyrobom kościanym i rogowym przypisuje się przeważnie funkcje użytkowe ${ }^{11}$, niemniej jednak w określonych przypadkach można $\mathrm{z}$ pewną dozą ostrożności skłaniać się ku odmiennym propozycjom interpretacyjnym. Zmarłych wyposażano także w pojemniki ceramiczne, najczęściej w typie pucharów, rzadziej amfor. Niektórzy badacze łączą ich obecność z uczestnictwem w tajemnych obrzędach zarezerwowanych dla wąskiego grona mężczyzn ${ }^{12}$. Jednym z elementów rytuału było spożywanie napojów alkoholowych. Funkcję naczyń libacyjnych miały spełniać wspomniane puchary. Konsumpcja alkoholu stanowiła najprawdopodobniej jeden $\mathrm{z}$ istotnych elementów rytuału, służyła ponadto zacieśnianiu więzi między uczestnikami ceremonii ${ }^{13}$.

\section{Kategorie militariów a płeć, wiek i układ zwłok zmarłych}

Obecność przywołanych kategorii militariów wykazuje ścisły związek z płcią i układem zwłok pochowanych. W znakomitej większości przypadków oręż towarzyszył osobnikom płci męskiej pochowanym na prawym boku. Zwyczaj ten jest szczególnie widoczny w przypadku toporów kamiennych (tab. 2). Jest to przy tym jedyna kategoria darów grobowych w typie oręża, których lokalizacja w jamie grobowej podlega ściśle określonym regułom. Odnajdywano je niemal zawsze za plecami zmarłego, na wysokości barków (na 53 analizowane groby odnotowano wyłącznie jedno odstępstwo od omawianej tradycji - obiekt $98 \mathrm{z}$ cmentarzyska w Mierzanowicach, stan. $1^{14}$ ). Niekiedy pozycja topora w grobie wyraźnie korespondowała z układem kości ramienia - najwyraźniej zmarły pierwotnie dzierżył w dłoni stylisko, na którego końcu osadzona była kamienna głowica broni. Omawiany przypadek najlepiej obrazuje sytuacja zarejestrowana w grobie $141 \mathrm{z}$ Żernik Górnych $^{15}$. Niezwykle konsekwentne przestrzeganie zwyczaju deponowania toporów kamiennych w ustalonej relacji przestrzennej względem szkieletu przemawia za ich wyjątkowym charakterem i stawia na pozycji jednego z najważniejszych materialnych wyznaczników tożsamości wojownika w g. K-S KCSz. Topory kamienne najczęściej stanowiły wyposażenie osób dorosłych w wieku maturus, rzadziej adultus. Warto jednak zaznaczyć, że w kilku przypadkach pojawiły się one w grobach dzieci. Przeważnie zmarłemu wkładano do grobu jeden egzemplarz. W związku z powyższymi uwagami przyjęło się traktować omawiane przedmioty jako wiarygodny wyznacznik zarówno płci, jak i liczby osób pochowanych w grobie.

Nie udało się jak dotąd precyzyjnie określić funkcji toporów kamiennych. Wobec sporadycznie wykonywanych analiz traseologicznych wnioskowanie na temat

\footnotetext{
${ }^{11}$ Włodarczak 2006, 36.

${ }^{12}$ Sherrat 1981; Czebreszuk 2001.

${ }^{13}$ Czebreszuk 2001.

${ }^{14}$ Uzarowiczowa 1970.

${ }^{15}$ Kempisty, Włodarczak 2000, 102.
} 
Tabela 2. Specyfika pochówków wyposażonych w topory kamienne

Table 2. Specificity of burials with stone axes

\begin{tabular}{|c|c|c|c|c|c|}
\hline Stanowisko/nr grobu & Liczba toporów & Płeć & Wiek & Głowa & Bok \\
\hline Kolosy kurhan $1 / 3$ & 1 & b.k. & b.k. & b.k. & b.k. \\
\hline Kolosy kurhan $1 / 4$ & 1 & b.k. & b.k. & b.k. & b.k. \\
\hline Miernów kurhan 2/2 & 1 & b.k. & b.k. & b.k. & b.k. \\
\hline Grębałów/b.d. & 1 & b.k. & b.k. & b.k. & b.k. \\
\hline Bosutów/3 & 1 & M & adultus/maturus? & SE & $\mathrm{P}$ \\
\hline Krzyż/2 & 1 & b.k. & b.k. & b.k. & b.k. \\
\hline Koniusza/3 & 1 & M & maturus & SW & $\mathrm{P}$ \\
\hline Koniusza/14 & 1 & M & maturus & $S$ & $\mathrm{P}$ \\
\hline Zielona/3 & 1 & M & maturus & $S$ & $\mathrm{P}$ \\
\hline Zielona/7 & 1 & b.k. & infans II & S & $\mathrm{P}$ \\
\hline Bronocice/b.d. & 1 & M & maturus & $\mathrm{S}$ & $\mathrm{P}$ \\
\hline Smroków 17 & 1 & M & adultus & $\mathrm{S}$ & $\mathrm{P}$ \\
\hline Nowy Daromin/5 & 1 & b.k. & b.k. & b.k. & b.k. \\
\hline Malice Kościelne/1 & 1 & M & maturus & $\mathrm{S}$ & $\mathrm{P}$ \\
\hline Malice Kościelne/3 & 1 & b.k. & juvenis? & $S$ & $\mathrm{P}$ \\
\hline Wójeczka/2 & 1 & b.k. & b.k. & b.k. & b.k. \\
\hline Wójeczka/3 & 1 & b.k. & b.k. & b.k. & b.k. \\
\hline Kleczanów/b.d. & 1 & b.k. & b.k. & b.k. & b.k. \\
\hline Witów/1 & 1 & M & b.k. & $S$ & $\mathrm{P}$ \\
\hline Witów/2 & 1 & b.k. & b.k. & \multicolumn{2}{|c|}{ kenotaf } \\
\hline Mierzanowice stan. 1/94 & 1 & M & b.k. & $S$ & $\mathrm{P}$ \\
\hline Mierzanowice stan. 1/98 & 1 & M & b.k. & SE & $\mathrm{P}$ \\
\hline Mierzanowice stan. 1/108 & 1 & M & b.k. & SW & $\mathrm{P}$ \\
\hline Mierzanowice stan. 1/111 & 1 & M K & adultus/adultus & $\mathrm{S}$ & $\mathrm{P}$ \\
\hline Dłubnia-Zesławice/b.d. & 1 & M & maturus & $\mathrm{S}$ & $\mathrm{P}$ \\
\hline Mierzanowice stan. 5/1 & 1 & b.k. & b.k. & \multicolumn{2}{|c|}{ ciałopalny } \\
\hline Wzgórza Krzesławickie/b.d. & 1 & b.k. & b.k. & b.k. & b.k. \\
\hline Łękawa/3 & 1 & M & adultus & $\mathrm{S}$ & $\mathrm{P}$ \\
\hline Żerniki Górne stan. 1/67 & 1 & M & maturus & b.k. & b.k. \\
\hline Żerniki Górne stan. 1/141 & 1 & M & maturus & $\mathrm{S}$ & $\mathrm{P}$ \\
\hline Żerniki Górne stan. 1/90 & 1 & K/b.k. & adultus/infans I & b.k. & b.k. \\
\hline Żerniki Górne stan. 1/132 & 1 & $\mathrm{M}$ & maturus & SW & $\mathrm{P}$ \\
\hline Żerniki Górne stan. 1/95 & 1 & M & maturus & SE & $\mathrm{P}$ \\
\hline
\end{tabular}


ich przeznaczenia jest utrudnione. Mogły być one wykorzystywane jako broń i pełnić jednocześnie funkcję materialnego wyznacznika statusu i roli społecznej jednostki ${ }^{16}$. Niewykluczone również, że znajdowały zastosowanie w pracach gospodarczych. Druga hipoteza wydaje się mniej wiarygodna ze względu na:

- występowanie toporów wyłącznie w grobach należących do osobników płci męskiej, pochowanych na prawym boku;

- konsekwentne przestrzeganie zasad deponowania toporów w określonej relacji przestrzennej względem szkieletu - zwyczaj ten nie dotyczy żadnej kategorii przedmiotów narzędziowych;

- powszechne występowanie siekier krzemiennych $\mathrm{w}$ grobach przedstawicieli obu płci.

Wymienione obserwacje przemawiają za uznaniem toporów kamiennych za broń oraz materialny wyznacznik określonej tożsamości, a być może także statusu.

Najliczniej występującą w grobach kategorię uzbrojenia stanowią krzemienne groty strzał (tab. 3). Pojawiły się w 30 grobach w łącznej liczbie 151 egzemplarzy. Liczba grotów w grobie wahała się od 1 do 16. Podobnie jak topory kamienne odnajdywano je przeważnie przy pochówkach męskich spoczywających na prawym boku, z głową skierowaną na południe. Zanotowano też kilka wyjątków od powyższej reguły (groby 127 i 137 z Żernik Górnych ${ }^{17}$ ). Relikty wyposażenia łuczniczego odkrywano za plecami lub, nieco rzadziej, w okolicach stóp zmarłego. Często tworzyły one koncentracje. Sporadycznie występowały w rozproszeniu, zalegając bezładnie na dnie jamy grobowej. Jedynie w dziewięciu grobach sprzęt łuczniczy zdeponowano $\mathrm{w}$ zestawie $\mathrm{z}$ toporem kamiennym.

Niewiele wiadomo na temat pojemników, w których przechowywano strzały. Do tej pory nie udało się bowiem odnaleźć żadnego zachowanego przedmiotu tego typu. Prawdopodobnie wykonywano je z nietrwałych materiałów organicznych, w związku z czym ulegały szybkiemu rozkładowi ${ }^{18}$. Istnieje jednak kilka przesłanek wskazujących na potencjalną obecność kołczanów wśród darów grobowych. Przyjmuje się, że gdy wierzchołki większej liczby grotów wchodzących w skład zwartej ich koncentracji wskazują ten sam kierunek, można przypuszczać, iż pierwotnie znajdowały się w kołczanie. Niestety w przypadku grobów g. K-S KCSz omawiana sytuacja występuje bardzo rzadko (zob. groby nr 100 i 199 z Mierzanowic, stan. $1^{19}$ ). Niekiedy nagromadzenia grotów odkrywa się w obrębie przebarwień o konsystencji odmiennej od otaczającego je calca. Przyjmuje się, że mogły one stanowić pozostałości po pojemnikach wykonanych, jak wspomniano wyżej, z nietrwałych materiałów organicznych.

Większość odnajdywanych grotów reprezentuje tzw. typ sercowaty. W g. K-S KCSz nie występuje wyraźny podział na groty z zadziorami i smukłe, wąskie egzem-

\footnotetext{
${ }^{16}$ Malmer 1989; Keeley 1996.

${ }^{17}$ Kempisty, Włodarczak 2000.

${ }^{18}$ Uzarowiczowa 1970, 205.

${ }^{19}$ Uzarowiczowa 1970.
} 
Tabela 3. Krzemienne groty strzał a wiek i płeć pochówków

Table 3. Flint arrowheads to age and sex ratio of the burials

\begin{tabular}{|c|c|c|c|c|}
\hline Stanowisko & $\mathrm{Nr}$ grobu & Płeć & Wiek & Liczba grocików \\
\hline Bosutów & 3 & b.d. & b.d. & 3 \\
\hline Krzyż & 2 & b.d. & b.d. & 8 \\
\hline Koniusza & 3 & $\mathrm{M}$ & maturus & 16 \\
\hline Zielona & 2 & M & maturus/senilis & 1 \\
\hline Zielona & 3 & $\mathrm{M}$ & maturus & 10 \\
\hline Złota & 15 & b.d. & b.d. & 8 \\
\hline Złota & 16 & b.d. & b.d. & 5 \\
\hline Nowy Daromin & 3 & b.d. & b.d. & 3 \\
\hline Nowy Daromin & 4 & b.d. & b.d. & 1 \\
\hline Malice Kościelne & 3 & b.d. & infans II & 1 \\
\hline Mierzanowice 1 & 81 & $\mathrm{M}$ & b.d. & 11 \\
\hline Mierzanowice 1 & 121 & b.d. & b.d. & 2 \\
\hline Mierzanowice 1 & 89 & $\mathrm{M}$ & b.d. & 15 \\
\hline Mierzanowice 1 & 94 & M & b.d. & 3 \\
\hline Mierzanowice 1 & 100 & M & b.d. & 9 \\
\hline Mierzanowice 1 & 108 & M & b.d. & 2 \\
\hline Mierzanowice 1 & 199 & M & b.d. & 13 \\
\hline Mierzanowice 1 & 200 & $\mathrm{M}$ & b.d. & 3 \\
\hline Mierzanowice 1 & 209 & M & adultus & 7 \\
\hline Łękawa & 4 & \multicolumn{2}{|c|}{ KENOTAF } & 7 \\
\hline Żerniki Górne 1 & $42 \mathrm{a}$ & $\mathrm{M}$ & maturus & 1 \\
\hline Żerniki Górne 1 & 85 & $\mathrm{M} / \mathrm{M}$ & maturus/maturus & 4 \\
\hline Żerniki Górne 1 & 67 & $\mathrm{M}$ & maturus & 1 \\
\hline Żerniki Górne 1 & 115 & $\mathrm{M}$ & maturus & 2 \\
\hline Żerniki Górne 1 & 127 & $\mathrm{M}$ & maturus & 1 \\
\hline Żerniki Górne 1 & 128 & $\mathrm{M}$ & maturus & 3 \\
\hline Żerniki Górne 1 & 132 & $\mathrm{M}$ & maturus & 5 \\
\hline Żerniki Górne 1 & 133 & M & maturus & 3 \\
\hline Żerniki Górne 1 & 136 & $\mathrm{M}$ & maturus & 2 \\
\hline Żerniki Górne 1 & 137 & $\mathrm{~K}$ & adultus & 1 \\
\hline
\end{tabular}

plarze o trójkątnej formie. Brak zróżnicowania morfometrycznego omawianej kategorii przedmiotów można ewentualnie tłumaczyć nierozróżnianiem egzemplarzy przeznaczonych do walki oraz polowania.

Siekiery krzemienne, w przeciwieństwie do elementów wyposażenia opisanych powyżej, stosunkowo często pojawiają się w grobach przedstawicieli obu płci ${ }^{20}$. Nie

\footnotetext{
${ }^{20}$ Włodarczak 2006.
} 
wykazują one zatem wyraźniejszych związków z płcią oraz układem zwłok zmarłych. Przy pochówku odnajdywano najczęściej jedną siekierę, rzadziej dwie. W jednym z 39 obiektów, w których odnotowano ich obecność, odkryto aż cztery egzemplarze (ryc. 2). Ogólnie rzecz ujmując, zaliczanie siekier do grupy przedmiotów o charakterze militarnym stanowi kwestię wysoce dyskusyjną. Najprawdopodobniej na co dzień wykorzystywano je w pracach ciesielskich i gospodarczych. Można jednak przypuszczać, że w razie zagrożenia mogły szybko przeistoczyć się w skuteczne narzędzie obrony.

\section{Liczba siekier krzemiennych w grobach}

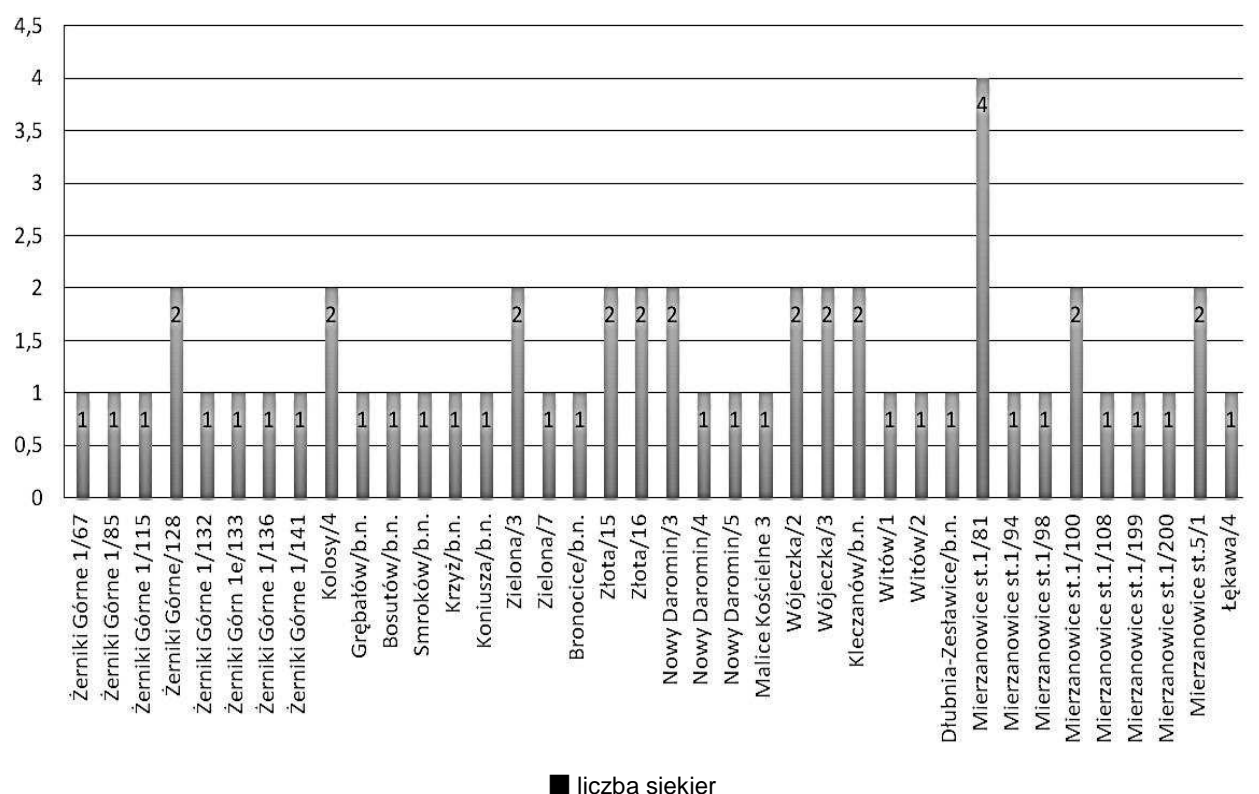

Ryc. 2. Siekiery z analizowanych grobów g. K-S KCSz

Fig. 2. Axes from the analysed CWC-KSG graves

W analizowanej grupie grobów ostrza krzemienne o proporcjach i wykończeniu sugerującym ich wykorzystanie w charakterze broni stanowiły element wyposażenia bogatych grobów należących do mężczyzn. Do cech wspólnych omawianych obiektów należy zaliczyć: obecność topora kamiennego, ułożenie zwłok na prawym boku, głowę skierowaną na południe oraz przeważnie męską płeć pochówku. Różnice dotyczą z kolei wieku pochowanych oraz pozostałych elementów wyposażenia. 


\section{KATEGORIE WOJOWNIKÓW W GRUPIE KRAKOWSKO- -SANDOMIERSKIEJ KULTURY CERAMIKI SZNUROWEJ}

Różnice w liczbie i jakości wyposażenia militarnego z grobów wojowników stanowią podstawę do wyróżnienia kilku ich kategorii (tab. 4, ryc. 3). Z łącznej liczby 53 grobów zaledwie w dziewięciu stwierdzono obecność topora kamiennego w zestawie ze sprzętem łuczniczym. Pięć z nich uznano za jedne z najbogatszych obiektów funeralnych $z$ terenu Wyżyny Małopolskiej ${ }^{21}$. Nie można zatem wykluczyć, że pochowani w nich zmarli wyróżniali się wysokim statusem społecznym, manifestowanym nie tylko poprzez bogactwo towarzyszących im przedmiotów, lecz również charakterystyczny zestaw militariów, tj. topór kamienny wraz ze sprzętem łuczniczym.

Tabela 4. Kategorie oręża a kategorie wojowników w zbiorze analizowanych pochówków grupy krakowsko-sandomierskiej $\mathrm{KCSz}$

Table 4. Categories of weapons to categories of warriors ratio within the analysed CWC-KSG burials

\begin{tabular}{|c|c|c|c|c|c|c|}
\hline \multirow[b]{2}{*}{ Stanowisko/nr grobu } & \multicolumn{3}{|c|}{ Kategorie oręża } & \multicolumn{3}{|c|}{ Kategorie wojowników } \\
\hline & 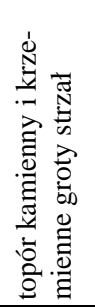 & 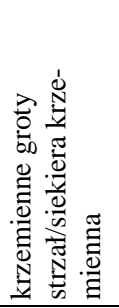 & 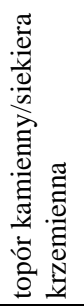 & 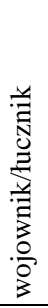 & 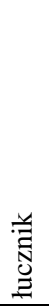 & $\begin{array}{l}\frac{y}{3} \\
\frac{0}{3} \\
0 \\
3\end{array}$ \\
\hline 1 & 2 & 3 & 4 & 5 & 6 & 7 \\
\hline Żerniki Górne 1/42a & & 1 & & & 1 & \\
\hline Żerniki Górne 1/67 & 1 & & & 1 & & \\
\hline Żerniki Górne 1/85 & & 1 & & & 1 & \\
\hline Żerniki Górne 1/90 & & & 1 & & & 1 \\
\hline Żerniki Górne 1/95 & & & 1 & & & 1 \\
\hline Żerniki Górne 1/115 & & 1 & & & 1 & \\
\hline Żerniki Górne 1/127 & & 1 & & & 1 & \\
\hline Żerniki Górne 1/128 & & 1 & & & 1 & \\
\hline Żerniki Górne 1/132 & 1 & & & 1 & & \\
\hline Żerniki Górne 1/133 & & 1 & & & 1 & \\
\hline Żerniki Górne 1/136 & & 1 & & & & \\
\hline Żerniki Górne 1/137 & & 1 & & & 1 & \\
\hline Żerniki Górne 1/141 & & & 1 & & & 1 \\
\hline Kolosy kurhan $1 / 3$ & & & 1 & & & 1 \\
\hline Kolosy kurhan 1/4 & & & 1 & & & 1 \\
\hline
\end{tabular}

${ }^{21}$ Włodarczak 2006, 145; Skrzyniecki 2012, 69. 
(cd. tab. 4)

\begin{tabular}{|c|c|c|c|c|c|c|}
\hline 1 & 2 & 3 & 4 & 5 & 6 & 7 \\
\hline Miernów kurhan 2/2 & & & 1 & & & 1 \\
\hline Grębałów & & & 1 & & & 1 \\
\hline Bosutów/3 & 1 & & & 1 & & \\
\hline Smroków 17/1 & & & 1 & & & 1 \\
\hline Krzyż/2 & 1 & & & 1 & & \\
\hline Koniusza/3 & 1 & & & 1 & & \\
\hline Koniusza/14 & & & 1 & & & 1 \\
\hline Zielona/2 & & 1 & & & 1 & \\
\hline Zielona/3 & 1 & & & 1 & & \\
\hline Zielona/7 & & & 1 & & & 1 \\
\hline Bronocice & 1 & & & 1 & & \\
\hline Złota/15 & & 1 & & & 1 & \\
\hline Złota/16 & & 1 & & & 1 & \\
\hline Nowy Daromin/3 & & 1 & & & 1 & \\
\hline Nowy Daromin/4 & & 1 & & & 1 & \\
\hline Nowy Daromin/5 & & & 1 & & & 1 \\
\hline Malice Kościelne 1/1 & & & 1 & & & 1 \\
\hline Malice Kościelne 1/3 & 1 & & & 1 & & \\
\hline Wójeczka/2 & & & 1 & & & 1 \\
\hline Wójeczka/3 & & & 1 & & & 1 \\
\hline Kleczanów & & & 2 & & & 2 \\
\hline Witów/1 & & & 1 & & & 1 \\
\hline Witów/2 & & & 1 & & & 1 \\
\hline Mierzanowice 1/81 & & 1 & & & 1 & \\
\hline Mierzanowice 1/89 & & 1 & & & & \\
\hline Mierzanowice 1/94 & 1 & & & 1 & & \\
\hline Mierzanowice 1/98 & & & 1 & & & 1 \\
\hline Mierzanowice $1 / 100$ & & 1 & & & 1 & \\
\hline Mierzanowice 1/108 & & & 1 & & & 1 \\
\hline Mierzanowice 1/111 & & & 1 & & & 1 \\
\hline Mierzanowice 1/121 & & 1 & & & 1 & \\
\hline Mierzanowice 1/199 & & 1 & & & 1 & \\
\hline Mierzanowice $1 / 200$ & & 1 & & & 1 & \\
\hline Mierzanowice 1/209 & & 1 & & & 1 & \\
\hline Dłubnia-Zesławice & & & 1 & & & 1 \\
\hline Mierzanowice 5/1 & & & 1 & & & 1 \\
\hline Łękawa/3 & & & 1 & & & 1 \\
\hline Łękawa/4 & & 1 & & & 1 & \\
\hline Wzgórza Krzesławickie & & & 1 & & & 1 \\
\hline SUMA & 9 & 21 & 25 & 9 & 21 & 25 \\
\hline
\end{tabular}




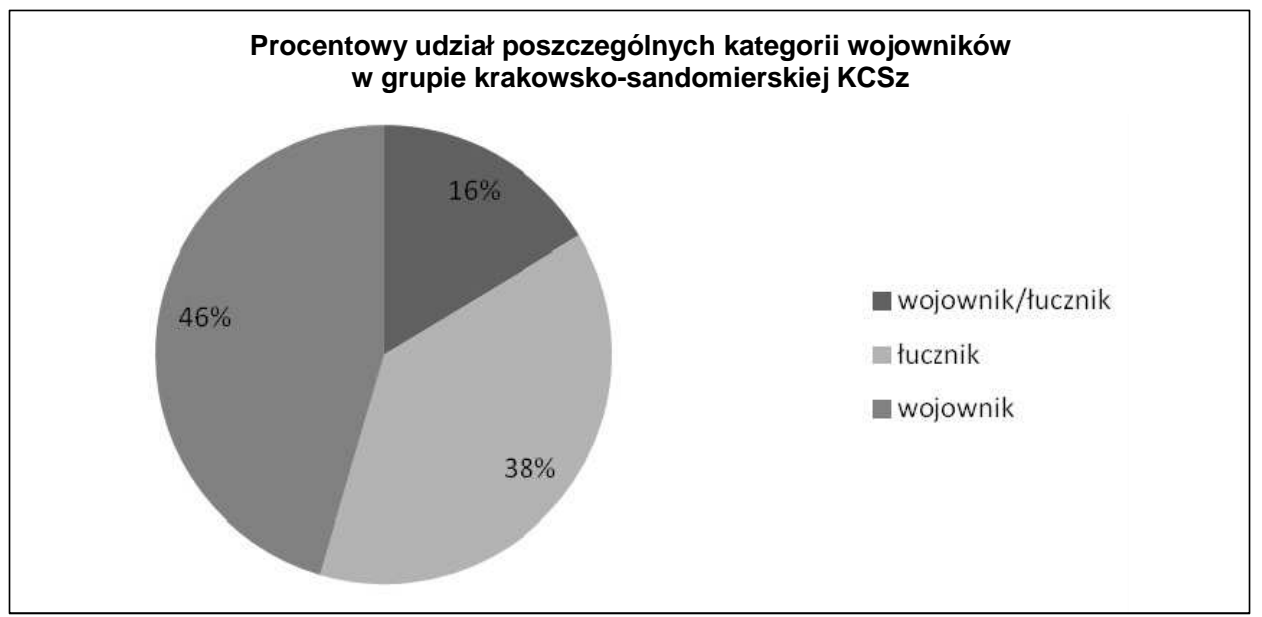

Ryc. 3. Procentowy udział poszczególnych kategorii wojowników w grupie analizowanych pochówków

Fig. 3. Percentage of various warrior categories within the analysed burials

Krzemienne groty strzał zarejestrowano w 30 grobach. W 21 przypadkach nie wystąpiły one w zespole z toporem kamiennym. Nie oznacza to jednak, że zmarłych $\mathrm{z}$ omawianych grobów pochowano bez oręża do walki w zwarciu. W 15 grobach towarzyszyły im jedna, dwie lub cztery siekiery krzemienne. Należy przy tym pamiętać, że omawiana kategoria darów grobowych występowała stosunkowo często w grobach należących do kobiet, wobec czego proste klasyfikowanie ich jako oręż nie jest właściwe. Można jednak z pewną dozą prawdopodobieństwa przyjąć, że w określonych okolicznościach mogły być one wykorzystywane jako substytut toporów kamiennych. Ponadto w okresie funkcjonowania społeczności g. K-S KCSz bronią podstawową mógł być łuk, za czym przemawia m.in. znaczna liczba znalezisk grotów strzał w grobach wojowników. W związku z tym ówczesne strategie prowadzenia działań wojennych koncentrowały się raczej na maksymalnie skutecznym wykorzystaniu korzyści płynących z posługiwania się bronią dystansową. Wobec tego walka wręcz mogła odgrywać rolę drugoplanową ${ }^{22}$.

Trzecią grupę grobów stanowią obiekty zawierające jedynie oręż do walki wręcz. Nieobecność reliktów sprzętu łuczniczego w omawianym kontekście może dziwić. Istnieje bowiem wiele przesłanek świadczących o dominującej roli łucznictwa w omawianym okresie dziejów. Ponadto przyjmuje się, że rozwój technik walki w zwarciu jest ściśle związany z wykształceniem się pierwszych organizacji o charakterze państwowym, ponieważ jedynie takie środowisko kulturowe stwarzało ku temu odpowiednie warunki. Brak krzemiennych grotów strzał w niektórych grobach wojowników g. K-S KCSz nie musi też wcale oznaczać, że osoby te nie opanowały

${ }^{22}$ Skrzyniecki 2012, 116-118. 
sztuki posługiwania się łukiem. Należy bowiem pamiętać, że doborem darów grobowych nie kierował przypadek. Deponowano je według ściśle określonych reguł determinujących przebieg rytuału pogrzebowego. Złożenie do grobu przedmiotu danej kategorii mogło mieć na celu przypisanie wyidealizowanej lub potwierdzenie „przeżytej” tożsamości zmarłego, reprezentowanej przez wskazaną kategorię kultury materialnej ${ }^{23}$. Dopuszcza się zatem co najmniej kilka interpretacji. Niewykluczone, że ów przedmiot mógł służyć zaakcentowaniu szczególnej sprawności pochowanej osoby w posługiwaniu się danym typem oręża. W grę wchodzi również symboliczna manifestacja przynależności do jednej z grup społecznych, dokonująca się poprzez sam fakt posiadania danego przedmiotu.

Warto w tym miejscu zaznaczyć, że przedmioty militarne, mimo że stanowiły przeważnie element wyposażenia dorosłych mężczyzn, odnajdywano również w grobach dzieci. Omawiane zjawisko dobrze ilustrują obiekty $\mathrm{nr} 90$ z Żernik Górnych $^{24}$ i 7 z Zielonej j5. W pierwszym z nich odkryto szczątki młodej kobiety i niemowlęcia, przy którym znajdował się topór kamienny miniaturowych rozmiarów. Wcześniej wspomniano, że obecność topora kamiennego w grobie często była uznawana za czynnik pomocny $w$ ustaleniu płci i liczby pochowanych $w$ danym grobie. Wykorzystując tę regułę, przypisano dziecku płeć męską, jako że w grupie krakowsko-sandomierskiej nie spotkano się jeszcze z przypadkiem odnalezienia przedmiotu tego typu przy szczątkach kobiety. Osobnik pochowany w grobie 7 z Zielonej zmarł w wieku infans II. Pochowano go zgodnie ze zwyczajem zarezerwowanym dla wojowników: ciało spoczywało na prawym boku z głową skierowaną na południe. Pochówek był wyposażony między innymi w topór kamienny, siekierę krzemienną oraz narzędzie wiórowe. Trudno zgodzić się z hipotezą o aktywnym uczestnictwie dzieci w ówczesnych konfliktach zbrojnych, wobec czego wyjaśnienia omawianej sytuacji należy szukać gdzie indziej. W przytoczonych przypadkach obecność topora kamiennego powinno się raczej odczytywać jako symboliczne poświadczenie przynależności do danej grupy społecznej oraz materialną reprezentację oczekiwań wspólnoty względem pochowanego - innymi słowy: głębokiej wiary $\mathrm{w}$ to, że po przekroczeniu stosownego wieku przeszedłby on pomyślnie rytuały inicjacji i został włączony w poczet wojowników. Trzeba zatem zaznaczyć, że obecność broni w grobie nie powinna być traktowana jako niepodważalny dowód na to, że osoba pośmiertnie w nią wyposażona była niegdyś wojownikiem. W określonych przypadkach tożsamość nadawana osobie po jej śmierci przez uczestników rytuału pogrzebowego odpowiadała w znacznym stopniu jej rzeczywistej roli za życia. Zdarzało się również, że zabieg ten miał wymiar stricte symboliczny i był ukierunkowany na pośmiertną idealizację jednostki. Próbując określić tożsamość zmarłego na

\footnotetext{
${ }^{23}$ Sarauw 2007.

${ }^{24}$ Kempisty, Włodarczak 2000.

${ }^{25}$ Włodarczak 2004.
} 
podstawie analizy pochówku, zawsze należy brać pod uwagę wszystkie dostępne informacje i unikać budowania swoich interpretacji na popularnych, aczkolwiek często niedostatecznie uzasadnionych sądach.

Zagadnienie nieobecności pewnych kategorii oręża, w szczególności zaś strzał, w grobach wojowników w g. K-S KCSz można rozpatrywać także na innej płaszczyźnie. Nie udało się bowiem dotychczas udowodnić, że przedstawiciele omawianych społeczności wykorzystywali jedynie strzały o grotach wykonanych z surowców nieorganicznych, w tym przypadku: z krzemienia. Równie skuteczne mogły okazać się egzemplarze o wierzchołkach uformowanych poprzez odpowiednie zaostrzenie drewnianego pręta. Przy dodatkowym założeniu, że praktyka zatruwania strzał przez maczanie ich w odpowiednich substancjach nie była tym ludziom obca, można mówić tutaj o orężu stanowiącym niezwykle ineresującą kombinację prostoty wykonania i śmiertelnej skuteczności. Strzały omawianego typu, ze względu na niską trwałość materiałów wykorzystanych do ich przygotowania, przeważnie nie zachowują się w zapisie archeologicznym ${ }^{26}$. Druga propozycja wskazuje na znaczenie krzemiennych grotów strzał jako materialnych wyznaczników tożsamości wojownika/myśliwego. Koncepcja ta $\mathrm{w}$ pewnym stopniu koresponduje $\mathrm{z}$ obecnością w grobach wojowników przedmiotów wykonanych z kości, poroża jelenia oraz szabli dzika. Przypuszcza się, że wykorzystywano je przede wszystkim w charakterze narzędzi, ale mogły również stanowić swoiste trofea myśliwskie. Świadczy o tym między innymi fakt, że często występują one w zespołach $\mathrm{z}$ wyposażeniem militarnym, w tym z krzemiennymi grotami strzał.

\section{MOŻLIWOŚCI REKONSTRUKCJI TECHNIK WALKI STOSOWANYCH PRZEZ WOJOWNIKÓW GRUPY KRAKOWSKO-SANDOMIERSKIEJ KULTURY CERAMIKI SZNUROWEJ}

Wojna prowadzona przez społeczności pierwotne pod wieloma względami odbiegała od standardów wytyczonych przez konflikty doby cywilizacji. Powyższe stwierdzenie odnosi się także do działań wojennych organizowanych przez populacje pradziejowe. Amerykański historyk wojskowości Harry Turney-High dokonał charakterystyki tzw. wojny pierwotnej (primitive warfare). W tym celu zastosował metodę porównawczą, zestawiając ze sobą konflikty społeczności przedpaństwowych i tych, które przekroczyły próg cywilizacji ${ }^{27}$. Dzięki temu udało mu się określić zarówno jej mocne, jak i słabe strony. Wojna pierwotna miała wybitnie ofensywny charakter; jej siła opierała się na perfekcyjnej znajomości terenu, dużej

\footnotetext{
${ }^{26}$ Keeley 1996; Underhill 1989, 221.

${ }^{27}$ Turney-High 1949, 21-137.
} 
mobilności wojowników oraz umiejętnym wykorzystaniu elementu zaskoczenia. Natomiast do słabych punktów zaliczono niski poziom wyszkolenia walczących, kulejącą dyscyplinę, brak logistyki, niską obronność osiedli oraz zbytnią ufność w skuteczność bojową poszczególnych jednostek. Przeprowadzone przez niego porównanie wyszło zdecydowanie na niekorzyść wojny pierwotnej, której przypisano niską skuteczność oraz rytualny, często bezkrwawy charakter ${ }^{28}$. $Z$ wieloma poglądami przywołanego autora można jednak dyskutować. Zapomniał on bowiem, że porównywane przez niego warianty prowadzenia działań wojennych zakorzenione są w dwóch zgoła odmiennych kontekstach kulturowo-gospodarczych. Oczywiste jest, że małe, egalitarne w swej organizacji społeczności przedpaństwowe dysponowały zdecydowanie bardziej prymitywnymi technologiami w zakresie pozyskiwania pożywienia i wytwarzania broni niż przedstawiciele pierwszych cywilizacji. Ich metody prowadzenia działań wojennych miały zatem charakter zupełnie odmienny od tego, co wielcy dowódcy pierwszych państw uważali za fundamentalne zasady skutecznej strategii. Nie znaczy to jednak, że omawiane różnice przekładały się na niską skuteczność wojowników społeczności ,pierwotnych”.

Wachlarz rozwiązań taktycznych stosowanych przez wojujące społeczności przedpaństwowe był stosunkowo szeroki. Uwzględniał on między innymi duże, planowane bitwy, oraz rozwiązania wykorzystujące element zaskoczenia, tj. zasadzki, najazdy i masakry ${ }^{29}$. Celem tych ostatnich była eksterminacja jak największej części populacji wrogiej osady w możliwie najkrótszym czasie. Najczęściej jednak działania wojenne przybierały formę najazdów i zasadzek.

Mimo znacznej liczby krzemiennych grotów strzał w inwentarzach KCSz, znany jest zaledwie jeden egzemplarz łuku. Stanowił on element wyposażenia lewobocznego pochówku żeńskiego, odkrytego pod nasypem kurhanu z miejscowości Bożejewice, woj. kujawsko-pomorskie. Przedmiot najprawdopodobniej spalono przed złożeniem do grobu, w związku z czym przeprowadzenie dodatkowych analiz nie było możliwe. Ustalono natomiast, że do jego wykonania użyto dwóch gatunków drewna ${ }^{30}$. Być może do stworzenia niektórych elementów omawianej konstrukcji wykorzystano także inne surowce organiczne, np. kości i ścięgna. Uwagę zwraca również charakterystyczne ukształtowanie łęczyska; nadano mu bowiem podwójnie wygięty kształt. Ze względu na przywołaną cechę łuk zaklasyfikowano jako półrefleksyjny. Przepalone przedmioty drewniane o wydłużonym kształcie odnajdywano również $w$ grobach przedstawicieli g. K-S KCSz. Dwa artefakty tego typu towarzyszyły pochówkowi mężczyzny z grobu $94 \mathrm{w}$ Mierzanowicach, stan. $1^{31}$. Niewykluczone, że pierwotnie stanowiły one jedną całość, być może łuk. Niestety oba fragmenty zaginęły, w związku z czym weryfikacja powyższej hipotezy nie jest możliwa. Stosowanie łuku jest

\footnotetext{
${ }^{28}$ Turney-High 1981, 26, 36-40.

${ }^{29}$ Keeley 1996, 59.

${ }^{30}$ Kośko, Kločko 1991.

${ }^{31}$ Uzarowiczowa 1970.
} 
przy tym wiarygodnie poświadczone $\mathrm{w}$ kontekście kultur neolitycznych $\mathrm{z}$ obszaru Europy; dobrze zachowane egzemplarze, datowane ogólnie na młodszą epokę kamienia, odkryto m.in. na Wyspach Brytyjskich ${ }^{32}$. Ponadto łuki stanowią jeden z głównych motywów malowideł naskalnych o tematyce wojennej z terenu hiszpańskiego Lewan$\mathrm{tu}^{33}$. Najnowsze badania potwierdziły ich neolityczną metrykę.

Jednym z podstawowych materialnych identyfikatorów KCSz, a zarazem kategorią darów grobowych ściśle związaną z tożsamością wojownika, są topory kamienne. W literaturze przedmiotu pojawiły się próby forsowania poglądu o ich symbolicznej funkcji, niemniej jednak przyjmuje się, że mogły służyć jako pełnoprawny oręż $^{34}$. Dopuszcza się również ich zastosowanie w charakterze narzędzia. Mimo prostej formy i niewielkich rozmiarów uważa się je za skuteczne narzędzie wojny. Należy jednak uwzględnić wiele istotnych utrudnień wiążących się z ich efektywnym użytkowaniem. Walka w bliskim kontakcie wiąże się, jak powszechnie wiadomo, z dodatkowym niebezpieczeństwem - wojownik naraża się bowiem na bezpośredni kontratak. Jeśli celem jest osoba posługująca się bronią dystansową, skrócenie dystansu stanowi dodatkowy problem. W trakcie pokonywania kolejnych metrów dzielących go od strzelca wojownik jest narażony na ciągły ostrzał. Ponadto wraz ze zbliżaniem się celu zwiększa się celność łucznika, w związku z czym wzrasta ryzyko trafienia i prawdopodobieństwo, że trafienie okaże się dla atakującego śmiertelne. Efektywne działanie w tak trudnych warunkach wymaga ogromnego doświadczenia, samodyscypliny oraz umiejętności działania $\mathrm{w}$ grupie ${ }^{35}$. Szanse przeżycia zwiększa również obecność dowódcy. Egalitarny model organizacji społeczeństwa reprezentowany przez społeczności przedpaństwowe, w tym prawdopodobnie także przez kulturę ceramiki sznurowej ${ }^{36}$, nie uwzględniał mechanizmów szkolenia i przymusu, niezbędnych do nabycia wyżej wymienionych umiejętności. Wojownik doby przedpaństwowej bazował przeważnie na indywidualnym wyszkoleniu; taktyki walki w oddziale były mu najprawdopodobniej obce. Można zatem przyjąć, że w warunkach dużej, regularnej bitwy, topory kamienne pełniły funkcję broni dodatkowej o charakterze pomocniczym ${ }^{37}$.

Według badaczy współczesnych społeczności przedpaństwowych regularne bitwy stanowią jeden z najrzadziej stosowanych wariantów działań wojennych ${ }^{38}$. Dominują rozwiązania wykorzystujące element zaskoczenia oraz znaczną mobilność niewielkich grup ,szturmowych”. Podobne metody mogli stosować przedstawiciele grupy krakowsko-sandomierskiej. Ludność o tradycji „sznurowej” z rejonu krakow-

\footnotetext{
${ }^{32}$ Mercer 1999.

${ }^{33}$ Nash 2005.

${ }^{34}$ Keeley 1996.

${ }^{35}$ Keeley 1996.

${ }^{36}$ Włodarczak 2006.

${ }^{37}$ Skrzyniecki 2012, 118.

${ }^{38}$ Buliński, Kairski 2006.
} 
sko-sandomierskiego funkcjonowała najprawdopodobniej w ramach niewielkich, stosunkowo ruchliwych grup. Ugrupowanie to rozwijało się w okresie zaniku wielkich, stabilnych osiedli i postępującego rozrzedzenia sieci osadniczej ${ }^{39}$. Znaczne odległości między poszczególnymi punktami osadniczymi oraz zanik dużych, niekiedy ufortyfikowanych osad, stworzyły idealne wręcz warunki do prowadzenia działań zaczepnych w typie niespodziewanych napadów, organizowanych przez kilku- lub co najwyżej kilkunastoosobowe grupy mężczyzn-wojowników. Tego typu operacje przeprowadzano z reguły pod osłoną nocy lub tuż przed wschodem słońca, kiedy mieszkańcy obserwowanej osady pogrążeni byli we śnie. Zaskoczone ofiary często nie były w stanie podjąć jakichkolwiek działań obronnych. Ogarnięci paniką ludzie zazwyczaj szukali wybawienia w ucieczce, odsłaniając się tym samym na ciosy i strzały przeciwników. W omawianych warunkach topór kamienny zyskiwał na znaczeniu. Ryzyko ucierpienia wskutek kontrataku spadało praktycznie do zera, ponadto zwolnienie z konieczności aktywnej obrony pozwalało na maksymalizację zadawanych obrażeń. Można zatem przyjąć, że topory kamienne używane przez społeczności g. K-S KCSz nie sprawdzały się w otwartym boju, natomiast znakomicie nadawały się do eksterminacji nieprzygotowanych do obrony mieszkańców wrogiej osady. Biorąc pod uwagę charakter oraz gęstość ówczesnego osadnictwa, należy przypuszczać, że to właśnie operacje, takie jak zasadzki i najazdy stanowiły dominujący wariant działań o charakterze zbrojnym.

Podobną funkcję mogły spełniać siekiery krzemienne, aczkolwiek ich związek z tożsamością wojownika nie jest tak wyraźny jak w przypadku toporów kamiennych. Odnajduje się je bowiem przy pochówkach przedstawicieli obu płci. Zauważono jednak, że egzemplarze pochodzące z grobów ludności g. K-S KCSz różnią się pod względem rozmiarów i jakości wykonania ${ }^{40}$. Co więcej, siekiery z grobów żeńskich były często mniejsze i nie tak starannie wykończone jak te odnajdywane przy pochówkach mężczyzn. O szczególnej roli tych przedmiotów świadczą m.in. analogie etnograficzne: np. mężczyźni z nowogwinejskiego ludu Mae Enga zawsze nosili masywne, solidnie wykonane siekiery zatknięte za pas, by w razie potrzeby użyć ich w charakterze broni. Kobiety także się nimi posługiwały - korzystały one jednak z egzemplarzy stosunkowo małych rozmiarów, wykorzystywanych przede wszystkim w lekkich pracach gospodarczych ${ }^{41}$. O używaniu siekier krzemiennych/kamiennych w charakterze oręża świadczą także uszkodzenia na czaszkach szkieletów odkrytych $\mathrm{w}$ grobie masowym z Tallheim, Niemcy, datowanym na V tys. BC. Przywołane uszkodzenia miały postać otworów, powstałych najprawdopodobniej w wyniku uderzenia ciężkim przedmiotem. Ich wielkość doskonale współgra z rozmiarami głowic kamiennych datowanych na omawiany okres ${ }^{42}$. Przytoczone przy-

\footnotetext{
${ }^{39}$ Kruk, Milisauskas 1999; Kruk 2008.

${ }^{40}$ Kempisty, Włodarczak 2000, 140.

${ }^{41}$ Petrequin, Jeunesse 1995, 15.

${ }^{42}$ Wahl, König 1987.
} 
kłady bynajmniej nie przekreślają funkcji narzędziowej siekier krzemiennych wskazują jedynie, że nie jest to jedyna możliwa interpretacja ich zastosowania. Przypadek ofiar z Tallheim pokazuje, że w razie potrzeby mogły one służyć za oręż, w dodatku śmiertelnie skuteczny. Nie można również wykluczyć, że w zbliżony sposób siekiery wykorzystywali przedstawiciele g. K-S KCSz.

\section{WNIOSKI}

Analizując różnice w wyposażeniu pochówków w g. K-S KCSz oraz związek poszczególnych jego kategorii z płcią, wiekiem oraz układem zwłok zmarłych można dojść do wniosku, że w ramach przywołanego ugrupowania obecna była charak-

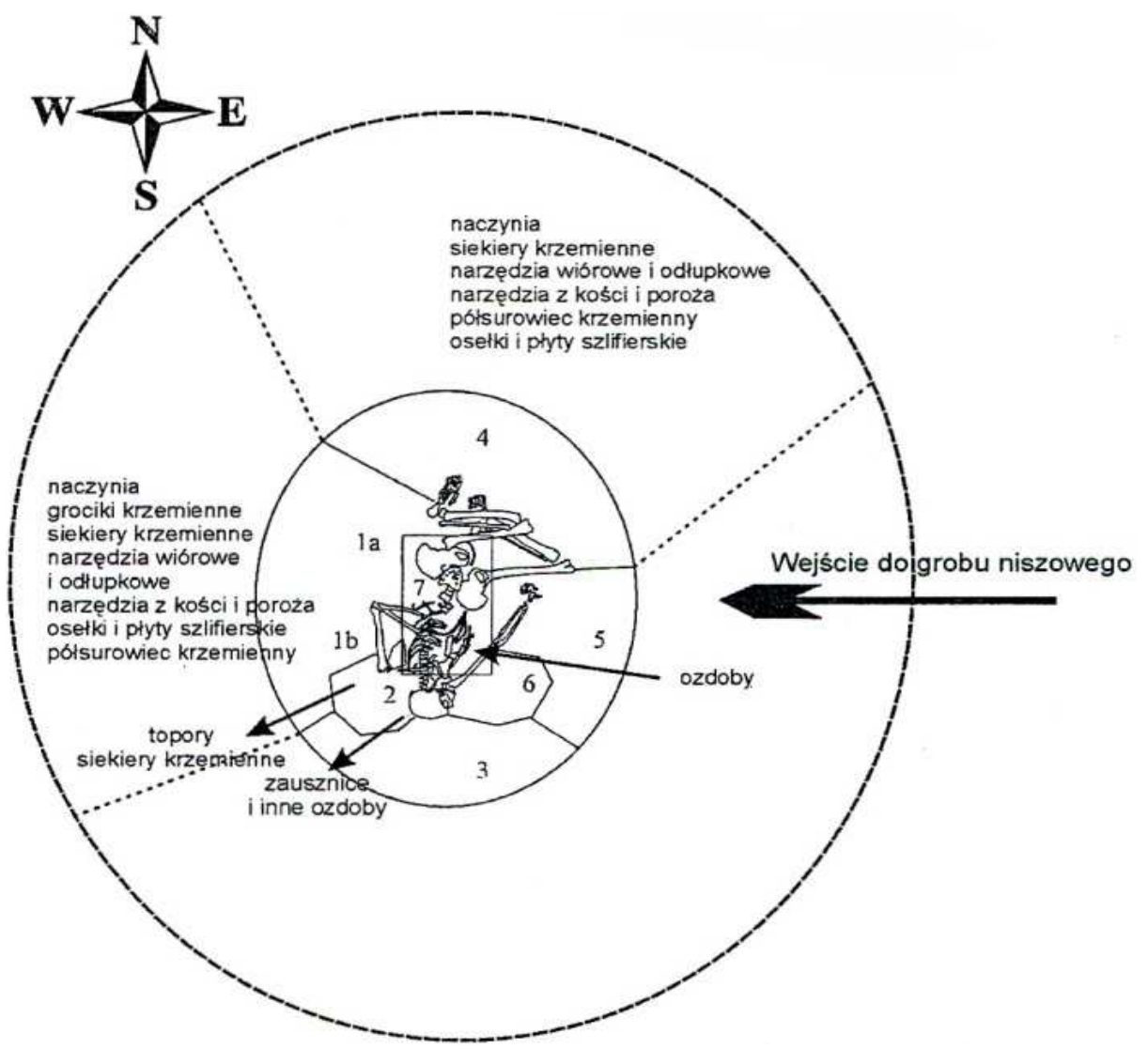

Ryc. 4. Schemat rozmieszczenia elementów wyposażenia w grobach KCSz z obszaru Małopolski (wg Włodarczak 2006)

Fig. 4. Schematic dispersion of goods in the CWK-KSG graves in Małopolska (according to Włodarczak 2006) 


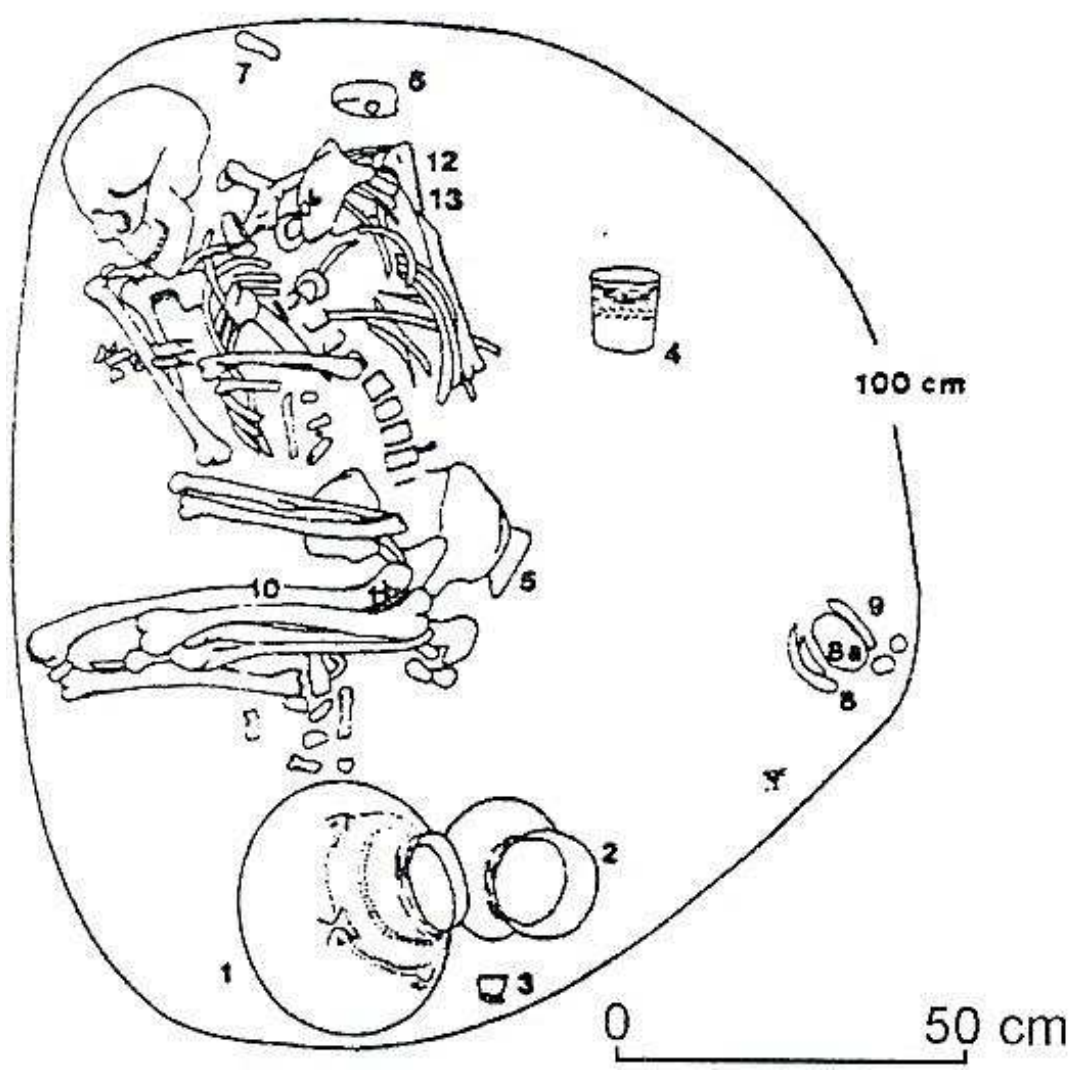

Ryc. 5. Grób z Bronocic - przykład klasycznego rozmieszczenia darów grobowych w grupie krakowsko-sandomierskiej KCSz (wg Milisauskas, Kruk 1984)

Fig. 5. A grave from Bronocice - an ex ample of typical dispersion of grave foods within the CWC-KSG (according to Milisauskas, Kruk 1984)

terrystyczna tożsamość związana z męskością, posiadaniem broni oraz najprawdopodobniej walką zbrojną, reprezentowana przede wszystkim przez tzw. groby wojowników. Ze wskazanych obiektów pochodzi pokaźny zestaw przedmiotów o charakterze militarnym, w tym toporów kamiennych, krzemiennych grotów strzał, ostrzy wiórowych oraz siekier krzemiennych. Artefakty tego typu odnajdywano niemal wyłącznie przy pochówkach spełniających określone warunki: musiał być to osobnik płci męskiej, najczęściej dorosły, pochowany ponadto na prawym boku, z głową skierowaną na południe. Warto przy tym odnotować, że w g. K-S KCSz nie wszystkich mężczyzn wyposażano pośmiertnie w oręż. Spora liczba pochówków męskich była go pozbawiona. Zwracają również uwagę różnice w liczbie oraz jakości przedmiotów militarnych w poszczególnych grobach. Być może przywołane zjawisko należałoby tłumaczyć odmiennym statusem społecznym poszczególnych 
wojowników (za czym przemawia także obecność wyjątkowo bogatych pochówków męskich $\mathrm{z}$ bronią). Ponadto w ramach jednego stowarzyszenia mogło funkcjonować nawet kilka ugrupowań, legitymizujących się odmiennym zestawem kultury materialnej. Generalnie jednak nieobecność broni w grobach zawierających pochówki męskie złożone na lewym boku przemawia za istnieniem ograniczonej liczebnie grupy mężczyzn reprezentujących kolektywny typ tożsamości ukierunkowanej na afirmację wartości związanych z walką i posiadaniem oręża. Hipoteza ta koresponduje z propozycją J. Kruka i S. Milisauskasa, których zdaniem w g. K-S KCSz doszło do wykształcenia się swoistego podziału zajęć: część mężczyzn trudniła się hodowlą, podczas gdy zadaniem innych była ochrona stad przed atakami ze strony złodziei i dzikich zwierząt ${ }^{43}$. Przywołana sytuacja społeczno-ekonomiczna stworzyła podstawy dla wykształcenia się grupy mężczyzn-wojowników (ryc. 4, 5). Członkowie tego typu stowarzyszeń, poprzez odpowiednie kreowanie swojego wizerunku oraz udział w rytuałach libacyjnych, stawali się aktywnymi reprezentantami zbiorowej tożsamości, co wiązało się ze szczególnym prestiżem i być może pociągało za sobą awans społeczny.

\section{BIBLIOGRAFIA}

Buliński T., Kairski J. (red.)

2006 Sny, trofea, geny i zmarli. „Wojna” w spotecznościach przedpaństwowych na przyktadzie Amazonii - przegląd koncepcji antropologicznych, Poznań.

Czebreszuk J.

2001 Schytek neolitu $i$ poczatki epoki brazu w strefie południowo-zachodniobattyckiej (III-II tys. przed Chr.). Alternatywny model kultury, Poznań.

Jenkins R.

1996 Social Identity, Routledge, London-New York.

Keeley L.H.

1996 War Before Civilisation, New York-Oxford.

Kempisty A., Włodarczak P.

2000 Cemetery of the Corded Ware Culture in Żerniki Górne, Warszawa.

Kośko A., Kločko V.

1991 Bożejewice, gm. Strzelno, woj. Bydgoszcz, stanowisko 8. Kurhan z późnego okresu epoki neolitu, Folia Praehistorica Posaniensia 4, s. 119-143.

Kruk J.

2008 Wzory przeszłości. Studia nad neolitem środkowym i późnym, Kraków.

Kruk J., Milisauskas S.

1999 Rozkwit i upadek społeczeństw rolniczych neolitu, Kraków.

Malmer M.P.

1989 Etnoarkeologiska synspunkter på stridsyxakulturen. Stridsyxakultur i Sydskandinavien [w:] Rapport från det andra nordiska symposiet om Stridsyxatid $i$ sydskandinavien, red. L. Larsson, Lund, s. 7-12.

\footnotetext{
${ }^{43}$ Milisauskas, Kruk 2002.
} 
Mercer R.J.

1999 The origins of warfare in the British Isles [w:] Ancient Warfare. Archaeological Perspectives, red. J. Carman, A. Harding, United Kingdom, s. 143-157.

Milisauskas S., Kruk J.

2002 Neolithic: Crisis, Collapse, New Ideologies and Economies [w:] European Prehistory. A Survey, red. S. Milisauskas, New York-Boston-Dordrecht-London-Moscow, s. 247-269.

Nash G.

2005 Assessing rank and warfare-strategy in prehistoric hunter-gatherer society: a study of representational warrior figures in rock-art from the Spanish Levant, southeastern Spain [w:] Warfare, Violence and Slavery in Prehistory, red. M.P. Pearson, I.J.N. Thorpe, BAR International Series 1374, s. 75-86.

Petrequin P., Jeunesse Ch. (red.)

1995 La hache de pierre. Carrières vosgiennes et échanges de lames polies pendant le Néolithique (5400-2100 av. J.C.), Paris.

Salewicz K.

1937 Tymczasowe wyniki badań prehistorycznych w Mierzanowicach (pow. opatowski, woj. kieleckie), Z Otchłani Wieków 12, s. 39-59.

Sarauw T.

2007 Male symbols or warrior identities? The "archery burials" of the Danish Bell Beaker Culture, Journal of Anthropological Archaeology 26, s. 65-87.

Sherrat A.

1981 Plough and pastoralism: aspects of the secondary products revolution [w:] European Social Evolution. Archaeological Perspectives, red. I. Hodder, G. Isaak, N. Hammond, Sussex, s. 123-134.

Skrzyniecki R.

2012 Tożsamość wojownika w grupie krakowsko-sandomierskiej kultury ceramiki sznurowej, Poznań [maszynopis pracy magisterskiej, Biblioteka Instytutu Prahistorii UAM].

Turney-High $\mathrm{H}$.

1949 Primitive War. Its Practice and Concepts, Columbia, s. 21-137.

1981 The Military:The Theory of Land Warfare as Behavioral Science, West Hanover, s. 26, 36-40.

Underhill A.

1989 Warfare During the Chinese Neolithic Period: A Review of the Exidence [w:] Cultures in Conflict, red. D. Tkaczuk, B. Vivian, Calgary, s. 219-237.

Uzarowiczowa A.

1970 Groby kultury ceramiki sznurowej z cmentarzyska wielokulturowego w Mierzanowicach, pow. Opatów, Wiadomości Archeologiczne 35/2, s. 201-234.

Vandkilde $\mathrm{H}$.

2006 Warriors and Warrior Institutions in Copper Age Europe [w:] Warfare and Society. Archaeological and Social Anthropological Perspectives, red. T. Otto, H. Thrane, H. Vandkilde, Aarhus, s. 393-422.

Wahl J., König H.G.

1987 Anthropologisch traumatologisch Unterschrung der menschlichen Skelettreste aus dem bandkeramischen Massengrab bei Talheim, Kreis Heilbronn, Funderberichte aus BadenWürtemberg 12, s. 65-193.

Włodarczak P.

2004 Cmentarzysko kultury ceramiki sznurowej w Zielonej, woj. małopolskie, Sprawozdania Archeologiczne 56, s. 307-360.

2006 Kultura ceramiki sznurowej na Wyżynie Małopolskiej, Kraków. 


\section{WARRIOR IDENTITY IN THE CRACOW-SANDOMIERZ GROUP OF CORDED WARE CULTURE}

\section{Su m m ary}

The study of differences in the Cracow-Sandomierz group of Corded Ware Culture (hereinafter referred to as CWC-KSG), grave goods and relations between their individual categories, sex, age, and body arrangement of the deceased leads to a conclusion that the group encompassed a specific type of identity related to manhood, possession of arms and, most likely, armed combat. The question of identity might be seen, above all, in the so-called warrior graves. These features yielded a considerable set of military objects, including stone battle-axes, flint arrowheads, flint blades and axes. Such artefacts were found almost exclusively together with burials, which met specific conditions: the deceased had to be male adults, lying on their right sides, with heads pointing south. Interestingly enough, in the CWC-KSG, not all men were posthumously outfitted with weapons. A considerable number of male burials had no weapons at all. Moreover, there are clear differences in the number and quality of military objects found in particular graves. The differences might be explained by the differences in the social status of warriors (exceptionally rich male burials with weapons are in favour of such explanation).

Furthermore, within one association, there could have operated even several groups characterized by different sets of material culture. As a rule, however, the absence of weapons in graves containing male burials lying on their left side is in favour of the existence of a small group of men sharing a collective identity, cherishing values related to combat and the possession of arms. This hypothesis is consistent with Janusz Kruk and Sarunas Milisauskas's proposal which holds that in the CWC-KSG, a peculiar division of tasks developed: some men were responsible for animal husbandry, while others took care of herds to keep them safe and beyond the reach of thieves and wild animals (Milisauskas, Kruk 2002). This division was conducive to the development of the group of men-warriors. The members of such groups or associations, by the skilful creating of their image and participating in libation rituals, became the active epitomes of a collective identity, which entailed special prestige and social promotion. 